\title{
Gas in the superior mesenteric artery
}

\author{
Sho Fujiwara, ${ }^{1,2}$ Yuki Sekine ${ }^{1,3}$
}

'Department of Surgery, Iwate Prefectural Chubu Hospital, Kitakami, Iwate, Japan ${ }^{2}$ Department of Molecular Pathology, Tohoku University School of Medicine, Sendai, Japan

${ }^{3}$ Department of Vascular Surgery, Iwate Prefectural Chubu Hospital, Kitakami, Iwate, Japan

\section{Correspondence to} Dr Sho Fujiwara, sho.fujiwara@med.tohoku.ac.jp

Accepted 7 March 2017
CrossMark

\footnotetext{
To cite: Fujiwara $S$, Sekine Y. BMJ Case Rep Published online: [please include Day Month Year] doi:10.1136/bcr-2017219470
}

\section{DESCRIPTION}

A woman aged 83 years with mediastinal tumour was admitted to our hospital with 2 days of abdominal pain. She had reduced consciousness and abdominal tenderness with peritoneal signs. Vital signs, physical examination and laboratory findings indicated sepsis and disseminated intravascular coagulation (DIC) with pan-peritonitis. Contrast-enhanced CT showed lack of enhancement in the intestinal and caecal wall, with intramural gas (figure 1A), portal venous gas (figure 1B) and gas in the superior mesenteric artery (SMA) (figure 1C). Diffuse intestinal necrosis with SMA occlusion was diagnosed. SMA thromboembolism was suspected and Trousseau's syndrome cannot be ruled out as the exacerbation factor. We performed bowel resection and anastomosis; portions of the small intestine, caecum and ascending colon were resected (figure 2). A total of $375 \mathrm{~cm}$ were resected, leaving $160 \mathrm{~cm}$ of the intestine. She recovered from sepsis and DIC and resumed feeding on postoperative day (POD) 2. However, she died on POD 27 due to progression of a mediastinal tumour.

SMA occlusion is a deadly disease. ${ }^{1}$ Findings of intramural gas and portal venous gas are typical in severe intestinal and mesenteric ischaemia. ${ }^{2}$ However, there are few reports on gas in the $\mathrm{SMA},{ }^{3}$ which is a rare finding.

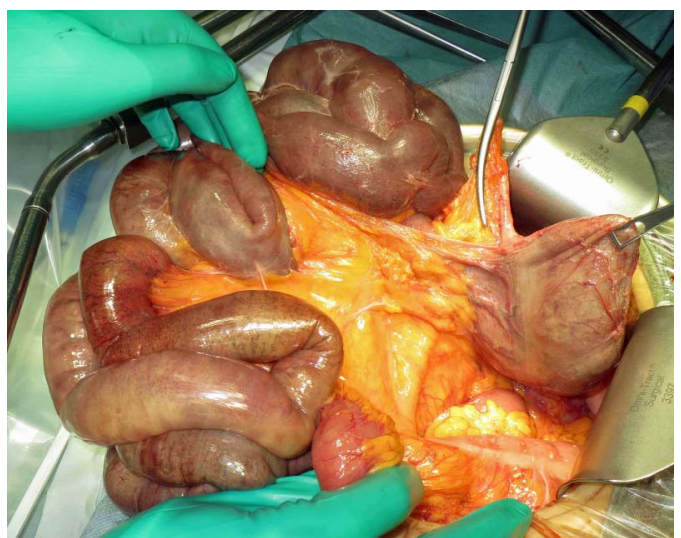

Figure 2 Operative findings showing severe necrotic small intestine and ascending colon with sharp demarcations.

\section{Learning points}

- Superior mesenteric artery (SMA) occlusion and mesenteric ischaemia are lethal conditions that are often difficult to diagnose without imaging.

- Prompt diagnosis and treatment are essential for recovery.

- Intramural gas and portal venous gas are often found. Gas in the SMA is very rare, but key to the recognition of severe mesenteric ischaemia.

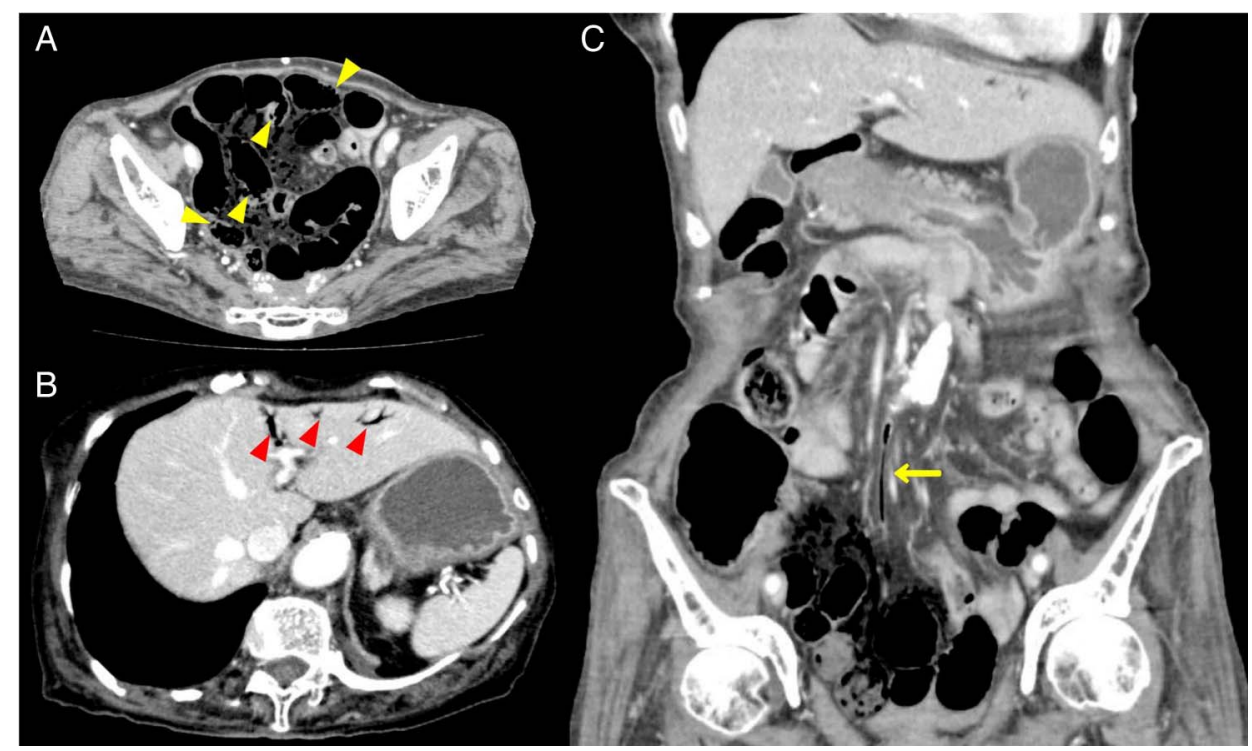

Figure 1 Axial contrast-enhanced CT showing a lack of enhancement in the intestinal wall and intramural gas (yellow arrowheads, A) and the liver showing a portal venous gas (red arrowheads, B). Coronal contrast-enhanced CT showing a gas in the superior mesenteric artery (yellow arrow, C). 
Contributors SF was involved in the design and revision of the article. YS was involved in the revision and final approval of the published version of the manuscript.

Competing interests None declared.

Patient consent Obtained.

Provenance and peer review Not commissioned; externally peer reviewed.

\section{REFERENCES}

1 Gupta PK, Natarajan B, Gupta $\mathrm{H}$, et al. Morbidity and mortality after bowel resection for acute mesenteric ischemia. Surgery 2011;150:779-87.

2 Clair DG, Beach JM. Mesenteric ischemia. N Engl J Med 2016;374:959-68.

3 Numata $S$, Tsutsumi $Y$, Ohashi H. Gas in the superior mesenteric artery: severe malperfusion and bowel necrosis caused by acute aortic dissection. Eur J Cardiothorac Surg 2013;43:1267-8.

Copyright 2017 BMJ Publishing Group. All rights reserved. For permission to reuse any of this content visit http://group.bmj.com/group/rights-licensing/permissions.

BMJ Case Report Fellows may re-use this article for personal use and teaching without any further permission.

Become a Fellow of BMJ Case Reports today and you can:

- Submit as many cases as you like

- Enjoy fast sympathetic peer review and rapid publication of accepted articles

- Access all the published articles

- Re-use any of the published material for personal use and teaching without further permission

For information on Institutional Fellowships contact consortiasales@bmjgroup.com

Visit casereports.bmj.com for more articles like this and to become a Fellow 